\title{
Recombinant somatolactin as a stable and bioactive protein in a cell culture bioassay: development and validation of a sensitive and reproducible radioimmunoassay
}

\author{
J A Calduch-Giner, C Pendón ${ }^{1}$, M M Valdivia ${ }^{1}$ and \\ J Pérez-Sánchez
}

Instituto de Acuicultura de Torre de la Sal, CSIC, 12595 Ribera de Cabanes, Castellón, Spain, and ${ }^{1}$ Sección Departamental de Bioquímica y Biología Molecular, Facultad de Ciencias, Universidad de Cádiz, 11510 Puerto Real, Cádiz, Spain

(Requests for offprints should be addressed to J Pérez-Sánchez)

\begin{abstract}
A recombinant somatolactin (SL) obtained by cloning and expression of sole SL cDNA was analyzed and used to develop a sensitive and specific RIA. In contrast to native proteins, which tend to dimerize and aggregate immediately after pituitary isolation, the majority of recombinant sole SL (rsSL) remained as a monomeric protein after long-term storage, as shown by size exclusion chromatography and Western blot. Using rsSL as a tracer and standard in the RIA, the minimum detectable dose and the midrange $\left(\mathrm{ED}_{50}\right)$ of the assay were $0 \cdot 15$ and $1 \cdot 8$ $2.1 \mathrm{ng} / \mathrm{ml}$ respectively. Intra- and interassay coefficients of variation were $4.3 \%$ and $6.5 \%$ at $\mathrm{ED}_{50}$ levels. Recombinant gilthead sea bream GH and recombinant trout $\mathrm{GH}$ did not show cross-reactivity, whereas a good parallelism
\end{abstract}

between rsSL standard and serial dilutions of plasma and sole pituitary extracts was observed. In order to demonstrate some biological activity of rsSL, the ability of this recombinant product to prime gilthead sea bream phagocytes for in vitro enhancement of mitochondrial activity was examined by a chromogenic assay. A bell-shape dose-response curve was obtained with a maximum at $50 \mathrm{nM}(1 \cdot 2 \mu \mathrm{g} / \mathrm{ml})$, similar to that reported previously for $\mathrm{GH}$. Therefore, taking together all these data, it appears conclusive that rsSL is a long-term stable protein which retains, at least in part, biological activity, providing a useful tool to clarify the physiological role of fish SL.

Journal of Endocrinology (1998) 156, 441-447

\section{Introduction}

Somatolactin (SL), a new member of the growth hormone $(\mathrm{GH})$ and prolactin (PRL) family, was initially isolated from Atlantic cod (Gadus morhua) pituitaries as a $26 \mathrm{kDa}$ glycoprotein (Rand-Weaver et al. 1991a). The corresponding protein was subsequently isolated from the pituitaries of Japanese flounder (Paralichthys olivaceus) (Ono et al. 1990), coho salmon (Oncorhynchus kisutch) (Planas et al. 1992, Rand-Weaver et al. 1992, Lu et al. 1995), chum salmon (Oncorhynchus keta) (Kakizawa et al. 1993), gilthead sea bream (Sparus aurata) (Cavari et al. 1995), red drum (Sciaenops ocellatus) (Zhu \& Thomas 1995), and halibut (Hippoglossus hippoglossus) (Johnson et al. 1997). In addition, SL clones have been isolated and characterized from cDNA libraries of Japanese flounder (Ono et al. 1990), Atlantic cod (Takayama et al. 1991a), chum salmon (Takayama et al. 1991a), lumpfish (Cyclopterus lumpus) (Iraqui et al. 1993), halibut (Iraqui et al. 1993), sole (Solea senegalensis) (Pendón et al. 1994) and gilthead sea bream (Astola et al. 1996), which indicates a high degree of homology (70-80\%), with seven cysteine residues in the consensus sequence, six of which are involved in disulfide bonding.

Immunocytochemical studies indicate that SLimmunoreactive cells are located in the pars intermedia of teleostean and holostean fish (Rand-Weaver et al. 1991b, Kaneko et al. 1993, Parhar \& Iwata 1994, Dores et al. 1996). These cells are periodic acid-Schiff positive in most species, but chromophobic in salmonids in which cloning and sequencing of cDNA SL shows a lack of Nglycosylation sites in the mature protein (Takayama et al. 1991b). The physicochemical and biochemical properties of SL are becoming, therefore, increasingly clear. Nevertheless, the formation of undesirable high molecular weight aggregates, due to aberrant interchain disulfide bonding and non-specific hydrophobic interactions, is the major problem limiting the final yield of monomeric SL. Recently, we have cloned and expressed the cDNA coding for sole SL (Pendón et al. 1996), and the aim of this work was to assess the suitability of the folding-purification procedure to obtain a bioactive and long-term stable 
protein preparation. The recombinant protein was analyzed by Western blot and size exclusion chromatography. In the absence of a well recognized bioassay, we examined the capacity of our recombinant sole SL (rsSL) for in vitro priming of gilthead sea bream phagocytes. Additionally, the use of this recombinant product as standard and radioligand in a sensitive and reproducible RIA is reported.

\section{Materials and Methods}

\section{Animals}

Blood and pituitary glands were taken in November from 2-year-old soles reared in running sea water under natural conditions of temperature and photoperiod at the fish farm of Cupimar (Cádiz, Spain). The animals were anesthetized with MS-222 (Sigma Chemical Company, St Louis, MO, USA), before killing by cervical section following CIOMS (Council for International Organizations of Medical Sciences) guidelines.

\section{Hormones}

Recombinant rainbow trout (Oncorhynchus mykiss) GH (rtGH) (lot no. BP19) was a gift of J Smal (Eurogentec, Liège, Belgium). Ovine GH (oGH) (lot no. AFP-9220A) was a gift of the National Institute of Health $(\mathrm{NIH})$ and the National Institute of Diabetes, Digestive and Kidney Diseases (NIDDK) (Bethesda, MD, USA). Recombinant gilthead sea bream GH (rsbGH) was obtained as described elsewhere (Martínez-Barberá et al. 1994). rsSL, expressed in E. coli BL21 cells, was first solubilized in guanidinium hydrochloride (6 M) and 2- $\beta$-mercaptoethanol (1\%). Renaturalization of the solubilized protein was performed by dialysis against $50 \mathrm{mM}\left(\mathrm{NH}_{4}\right) \mathrm{HCO}_{3}(\mathrm{pH} 7 \cdot 8)$. The resulting recombinant product was lyophilized, solubilized with $20 \mathrm{mM}$ Tris- $\mathrm{HCl}(\mathrm{pH} 8 \cdot 0)$, and purified to homogeneity by gel filtration on a Superose 6 HR column (Pharmacia Fine Chemicals, Piscataway, NJ, USA) (Pendón et al. 1996). Fractions containing the monomeric form were pooled, and stored as a lyophilized powder for more than 1 year at $-30{ }^{\circ} \mathrm{C}$.

\section{Purity and stability}

rsSL was dissolved in $\mathrm{NaOH}(10 \mathrm{mM})$, and $50 \mathrm{mM}$ Tris- $\mathrm{HCl}$ buffer $(\mathrm{pH} 7 \cdot 5)$ was rapidly added to reach a final protein concentration of $1-2 \mathrm{mg} / \mathrm{ml}$. The resulting protein suspension was chromatographed through a Protein Pak $300 \mathrm{sw}$ column $(30 \times 0.75 \mathrm{~cm})$ (Waters Corporation, Milford, MA, USA), calibrated before use with molecular weight markers (Bio-Rad, Hercules, CA, USA). The column was eluted with $50 \mathrm{mM}$ Tris- $\mathrm{HCl}$ buffer ( $\mathrm{pH} 7 \cdot 5$ ), containing $0.1 \mathrm{M} \mathrm{NaCl}$ and $0.02 \%$ sodium azide, at a flow rate of $30 \mathrm{ml} / \mathrm{h}$. oGH and $\mathrm{rtGH}$ were chromatographed for comparative purposes, and absorbance was monitored at $280 \mathrm{~nm}$ in an ultraviolet monitor (Pharmacia). rsSL was further characterized by SDS-PAGE and Western blot, using a rabbit antiserum $(1 / 5000)$ raised in female rabbits. Immunostaining was carried out with a peroxidase-conjugate and 4-chloro-1naphthol as chromogenic substrate (Sigma). Pituitary culture medium containing the native sole SL was used as a reference. For this purpose, isolated pituitary glands were incubated at $22{ }^{\circ} \mathrm{C}$ for $48 \mathrm{~h}$ in 96 -well plates with $200 \mu \mathrm{l}$ of complete medium: RPMI 1640 (Sigma), supplemented with 10\% fetal calf serum (Serva, Heidelberg, Germany).

\section{Hormone-specific antiserum}

Female rabbits were immunized against rsSL as follows: $200 \mu \mathrm{g} \mathrm{rsSL}$ in $0.5 \mathrm{ml}$ PBS, emulsified in $0.5 \mathrm{ml}$ complete Freund's adjuvant, were injected subcutaneously. Two hundred micrograms of rsSL in PBS and incomplete Freund's adjuvant were administered at 3, 6, 9 and 12 weeks after the first injection. Seven days after the last booster, blood was collected from the ear vein. After coagulation at $37{ }^{\circ} \mathrm{C}$ for $2-3 \mathrm{~h}$, blood was centrifuged for $20 \mathrm{~min}$ at $3000 \boldsymbol{g}$ to remove clotted cells. The clarified serum was stored at $-30{ }^{\circ} \mathrm{C}$ until further use.

\section{Radioiodination}

rsSL was iodinated by the chloramine $\mathrm{T}$ method as described elsewhere (Pérez-Sánchez et al. 1994). Unreacted iodine was separated by gel filtration on a Sephadex G-25 column (PD10, Pharmacia). The tracer was repurified through a Sephacryl S-200 (Pharmacia) column $(50 \times 0.7 \mathrm{~cm})$. The column was eluted with $20 \mathrm{mM}$ Tris- $\mathrm{HCl}$ ( $\mathrm{pH} 7 \cdot 5$ ), containing $0 \cdot 15 \mathrm{M} \mathrm{NaCl}$, $0.02 \%$ sodium azide and $0.3 \%$ BSA (RIA grade, Sigma), at a flow rate of $30 \mathrm{ml} / \mathrm{h}$. Specific activity ranged between 50 and $70 \mu \mathrm{Ci} / \mu \mathrm{g}$. Iodinated rsSL was stored in $50 \%$ glycerol at $-20{ }^{\circ} \mathrm{C}$, and was stable for more than 2 months.

\section{$R I A$ procedure}

The assay was performed using a double-antibody method under disequilibrium conditions as previously described for native and recombinant gilthead sea bream GH (Le Bail et al. 1993, Martínez-Barberá et al. 1995). Rabbit antiserum against rsSL was added at an initial ratio of $1 / 125000$ to $200 \mu \mathrm{l}$ of standard and unknown samples supplemented with non-immunized serum $(1 / 500)$ in $50 \mathrm{mM}$ Tris- $\mathrm{HCl}$ buffer ( $\mathrm{pH} 7 \cdot 5$ ), containing $10 \mathrm{mM}$ $\mathrm{MgCl}_{2}, 0 \cdot 1 \%$ Triton $\mathrm{X}-100,0 \cdot 05 \%$ sodium azide and $1 \%$ BSA. After overnight incubation at $15{ }^{\circ} \mathrm{C}, 9000$ 10000 c.p.m. of tracer in assay buffer were added to each tube, and incubation continued for $24 \mathrm{~h}$ at $15^{\circ} \mathrm{C}$. The antibody-bound hormone was precipitated by adding $100 \mu \mathrm{l}$ of sheep anti-rabbit gamma globulin, diluted $1 / 5$ in $50 \mathrm{mM}$ Tris- $\mathrm{HCl}(\mathrm{pH} 7 \cdot 5)$ containing $10 \mathrm{mM} \mathrm{MgCl}_{2}$ and 
$0.05 \%$ sodium azide. The incubation was continued overnight, and the assay was terminated by adding $3 \mathrm{ml}$ of the last $50 \mathrm{mM}$ Tris- $\mathrm{HCl}$ buffer. The tubes were then centrifuged for $45 \mathrm{~min}$ at $3000 \mathrm{~g}$. The supernatant was decanted and the radioactivity in the bound fraction was determined in a Packard gamma counter with an efficiency of $75 \%$.

\section{Bioactivity}

To test the bioactivity of rsSL, an assay involving the cleavage of XTT (sodium 3'-[phenyl-amino-carbonyl3,4-tetrazolium]-bis-(4-methyl-6-nitro)-benzene sulfonic acid hydrate) by gilthead sea bream phagocytes was used (Calduch-Giner et al. 1997). Briefly, head kidney was homogenized in PBS, and the resulting cell suspension allowed to settle for $30 \mathrm{~min}$. The upper fraction was decanted from the undissociated tissue, centrifuged at $400 \mathrm{~g}$ for $15 \mathrm{~min}$ and resuspended in culture medium. The resulting cell suspension was further allowed to sediment for $15 \mathrm{~min}$ on ice. The cell concentration in the upper fraction was determined in a hemocytometer, and adjusted to $7-8 \times 10^{6}$ leukocytes $/ \mathrm{ml}$ in the culture medium. The culture medium, isosmotic to gilthead sea bream serum

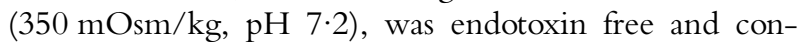
sisted of Leibovitz medium (L-15, Sigma), supplemented with L-glutamine $(0 \cdot 3 \mathrm{~g} / \mathrm{l}$, Sigma), $0 \cdot 1 \%$ fetal calf serum, $0.25 \mu \mathrm{g}$ fungizone $/ \mathrm{ml}, 100 \mathrm{IU}$ potassium penicillin $/ \mathrm{ml}$ and $100 \mathrm{IU}$ streptomycin sulfate/ml (Serva).

The enriched leukocyte fraction was seeded in 96-well plates $(100 \mu \mathrm{l} /$ well $)$, and incubated overnight at $24{ }^{\circ} \mathrm{C}$ in a humidified chamber. Non-adherent cells were discarded by several washings with PBS. The remaining cells (macrophages, 80\%; neutrophils, 20\%) were incubated in the culture medium $\left(24^{\circ} \mathrm{C}\right)$ with/without rsSL. After 5-6 h of priming culture, phagocytes were pulsed with an XTT solution (final concentration $0.3 \mathrm{mg} / \mathrm{ml}$ ), which is cleaved by mitochondrial dehydrogenases to form an orange formazan dye. The yield color was measured $4-6 \mathrm{~h}$ later in an ELISA plate reader (Bio-Rad) at $495 \mathrm{~nm}$ with a reference wavelength of $650 \mathrm{~nm}$. For comparative purposes, the effect of bacterial lipopolysaccharide (LPS, Salmonella thyphimurium, Sigma) on XTT cleavage was monitored.

\section{Statistical analysis}

The data were examined for significance by one-way ANOVA, followed by a Student-Newman-Keuls test. In the RIA procedure, curve parallelism between rsSL and serial dilutions of hormones, plasma and pituitary homogenates was tested by covariance analysis $(P<0 \cdot 05$ was considered statistically significant).

\section{Results and Discussion}

The target organ(s) and physiological significance of fish SL remain uncertain, although a role in reproduction
(Planas et al. 1992, Rand-Weaver et al. 1992, Olivereau \& Rand-Weaver 1994), stress (Rand-Weaver et al. 1993), smoltification (Rand-Weaver \& Swanson 1993), calcium regulation (Kakizawa et al. 1993, Kaneko \& Hirano 1993), metabolic activity (Rand-Weaver et al. 1995) and background adaptation (Zhu \& Thomas 1995) has been suggested, based on the factors which evoke changes in pituitary and circulating SL levels. At the present time, coho salmon (Rand-Weaver et al. 1992), chum salmon (Kakizawa et al. 1993), red drum (Zhu \& Thomas 1995) and halibut (Johnson et al. 1997) SLs have been used to develop fish SL RIAs. However, in both these and other assays, a major problem is the tendency of purified SL to dimerize and aggregate rapidly following isolation.

The monomeric form of coho salmon SL increases transepithelial phosphate reabsorption by winter flounder (Pleuronectes americanus) renal tubules (Lu et al. 1995). A weak effect has been reported on coho salmon steroidogenesis, but this effect was only found within $24 \mathrm{~h}$ of SL purification from pituitary extracts (Planas et al. 1992). In fact, as has been indicated by Rand-Weaver and coworkers (1992), coho salmon SL can dimerize and aggregate even in the lyophilized state. In a similar way, Zhu \& Thomas (1995) showed that red drum SL aggregates immediately after chromatographic separation, decreasing the recovery of the monomeric form with the storage of gel filtration fractions at $4{ }^{\circ} \mathrm{C}$. Therefore, as indicated by those authors, the use of red drum and coho salmon SL in the RIA procedure is limited to a few days after purification. In contrast, as determined by size exclusion chromatography, up to $95 \%$ of rsSL is conserved after 1 year of storage as a monomer with an apparent molecular weight of $22-23 \mathrm{kDa}$ (Fig. 1). Using an rsSL antiserum, a single immunoreactive band was found by Western blot following SDS-PAGE under non-reducing conditions. Moreover, as indicated previously (Pendón et al. 1996, 1998), the electrophoretic mobility of rsSL was equal to that reported for the native protein in its non-glycosylated form (Fig. 2). Nevertheless, different degrees of aggregation were observed when the expressed protein was solubilized in $10 \mathrm{mM} \mathrm{NaOH}$ before the addition of $20 \mathrm{mM}$ Tris- $\mathrm{HCl}$ (pH 8.0) in the chromatographic purification procedure (data not shown). This undesirable effect was not found when the folding product was directly solubilized in Tris- $\mathrm{HCl}$ buffer, probably due to the low solubility of reactive folding intermediates at $\mathrm{pH} 8 \cdot 0$. However, when the purified rsSL (stored without reactive folding intermediates) was used for routine assays, it was first dissolved with $10 \mathrm{mM} \mathrm{NaOH}$ to ensure a total solubilization of the lyophilized protein.

rsSL remained stable after iodination, with a percentage of deiodination near to $10 \%$ after 1 month of storage. In agreement with this, using a 15 -day-old tracer, up to $90 \%$ of ${ }^{125} \mathrm{I}-\mathrm{rsSL}$ could be precipitated after overnight incubation with a high concentration of rsSL antiserum. To evaluate further the binding affinity of this antiserum, a 


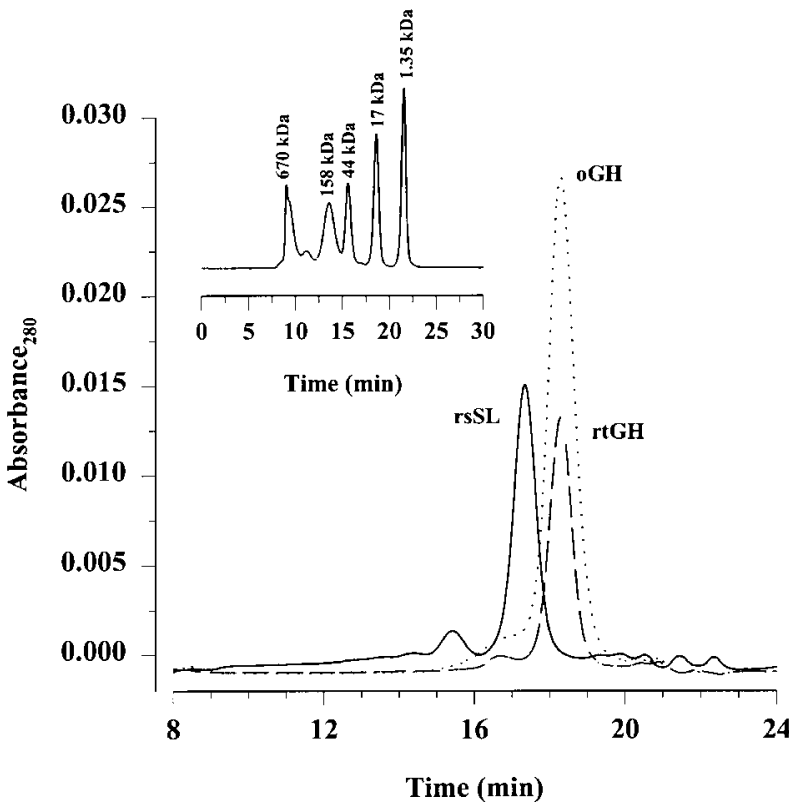

Figure 1 Chromatographic profile of oGH $(2 \mathrm{mg} / \mathrm{ml}), \mathrm{rtGH}$ $(1 \mathrm{mg} / \mathrm{ml})$, and rsSL $(1 \cdot 3 \mathrm{mg} / \mathrm{ml})$ on a Pak $300 \mathrm{sw}$ column $(30 \times 0.75 \mathrm{~cm})$; loop $20 \mu \mathrm{l}$, flow rate $30 \mathrm{ml} / \mathrm{h}$. The inset shows the chromatographic profile of molecular weight markers, including bovine thyroglobulin $(670 \mathrm{kDa})$, bovine gamma globulin $(158 \mathrm{kDa})$, chicken ovalbumin $(44 \mathrm{kDa})$, horse myoglobin $(17 \mathrm{kDa})$ and vitamin B-12 (1.35 kDa).

fixed amount of radioligand (9000 c.p.m.) was incubated overnight with serial dilutions of the antiserum $(1 / 2000$ $1 / 4000000)$. The transformation Scatchard plot of data showed two major populations of SL-binding sites, with affinity constants of 7.5 and $1.3 \times 10^{10} \mathrm{l} / \mathrm{mol}$ respectively (Fig. 3). This high binding affinity shows that $50 \%$ of the tracer can be bound with a relatively high dilution of the antibody $(1 / 125000)$. Thus, in the RIA procedure, the antiserum was used at a final dilution of 1/500 000, which precipitates up to $40 \%$ of total counts added (9000-10 000). The non-specific binding was $1.5 \%$, and the midrange of the assay $\left(\mathrm{ED}_{50}\right)$ was $1 \cdot 8-2 \cdot 1 \mathrm{ng} / \mathrm{ml}$, which is significantly lower than that found in previous assays, in which the $\mathrm{ED}_{50}$ value was $3 \cdot 1 \mathrm{ng} / \mathrm{ml}$ (Zhu \& Thomas 1995), $6.4 \mathrm{ng} / \mathrm{ml}$ (Rand-Weaver et al. 1992), $11.6 \mathrm{ng} / \mathrm{ml}$ (Kakizawa et al. 1993) and $36.0 \mathrm{ng} / \mathrm{ml}$ (Johnson et al. 1997) for red drum, coho salmon, chum salmon and halibut SL RIAs respectively.

In our assay system, repeated determinations of the SL concentration in a plasma pool $(2 \cdot 4 \mathrm{ng} / \mathrm{ml})$ gave intra- and interassay coefficients of variation of $4.3 \%(n=8)$ and $6.5 \%$ $(n=5)$ respectively. The recovery of rsSL, calculated as the slope of the linear regression of the amount of SL added to plasma and that recovered, was near $100 \%$ over the entire range assayed (Fig. 4). Furthermore, as shown in Fig. 5, displacement curves resulting from serial dilutions of plasma and pituitary extracts were parallel to the standard

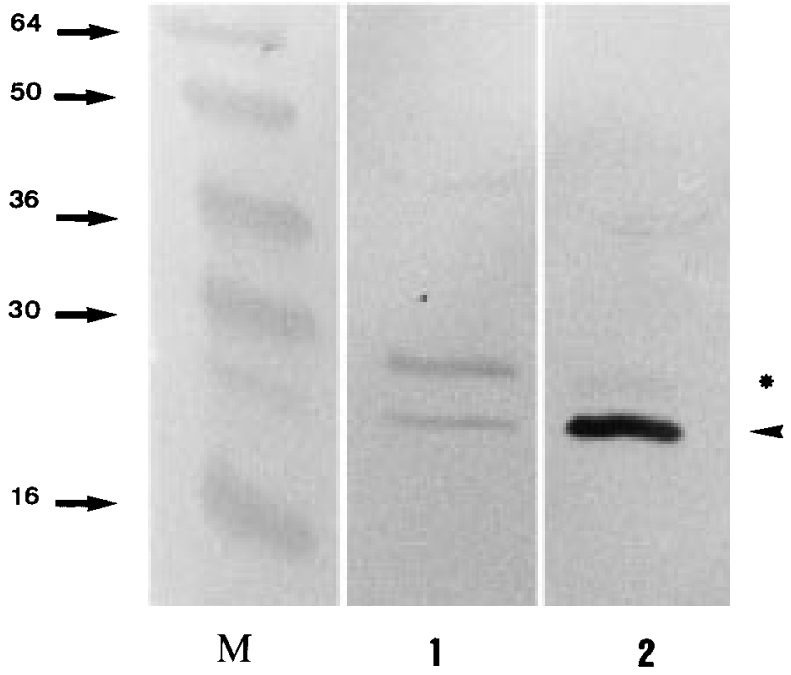

Figure 2 Immunoreactivity of native SL and rsSL with a polyclonal serum against rsSL. Lane $\mathrm{M}$, protein markers $(\mathrm{kDa})$. Note the presence of two different forms of native SL in the pituitary culture medium (lane 1) (the putative glycosylated form is shown by an asterisk). rsSL (lane 2) runs identically to the non-glycosylated form.

curve. $\mathrm{rtGH}$ and rsbGH did not cross-react in the assay, while pituitary extracts from gilthead sea bream and sea bass (Dicentrarchus labrax) were recognized at relatively low concentrations. However, the resulting slopes did not parallel the standard curve (data not shown), probably due to differences in SL sequence between the different orders of bony fish. Therefore, taking into account all these results, it appears conclusive that rsSL provides a useful tool to develop a sensitive and specific assay to measure plasma and pituitary SL levels, avoiding the problems of dimerization and aggregation of the tracer and/or unlabeled hormone.

The demonstration of purity, identity and stability of rsSL monomer is not sufficient to prove biological activity because all of the chemical and physical aspects contributing to SL bioactivity are not known. An SL bioassay is needed, therefore, as an adjunct to liquid chromatography and SDS-PAGE. Some success has been reported with in vitro culture of red drum scales (Zhu \& Thomas 1997), and primary monolayer cultures of flounder renal tubules (Lu et al. 1995). Nevertheless, the large dose (500 nM) required to elicit melanosome aggregation in the former, and the long and tedious procedure to quantify phosphate reabsorption in the latter (15 days) did not allow the development of a routine assay for biopotency measurement. In this context, it is of interest that both GH and PRL exert a direct effect upon mammalian leukocytes (Gala \& Shevach 1993, Murphy et al. 1995), and we cannot exclude the possibility that a new member of the GH/PRL family would also exert some immunoregulatory actions. In this regard, it must be noted that the 


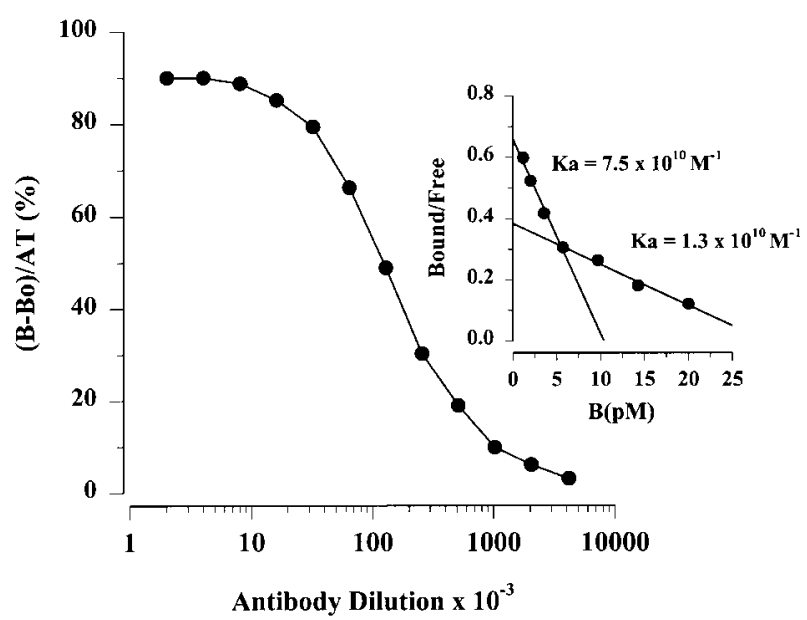

Figure 3 Binding of ${ }^{125} \mathrm{I}$-rsSL (9000 c.p.m.) to serial dilutions of rsSL antiserum. Inset is a transformation Scatchard plot of data (Ka; affinity constant).

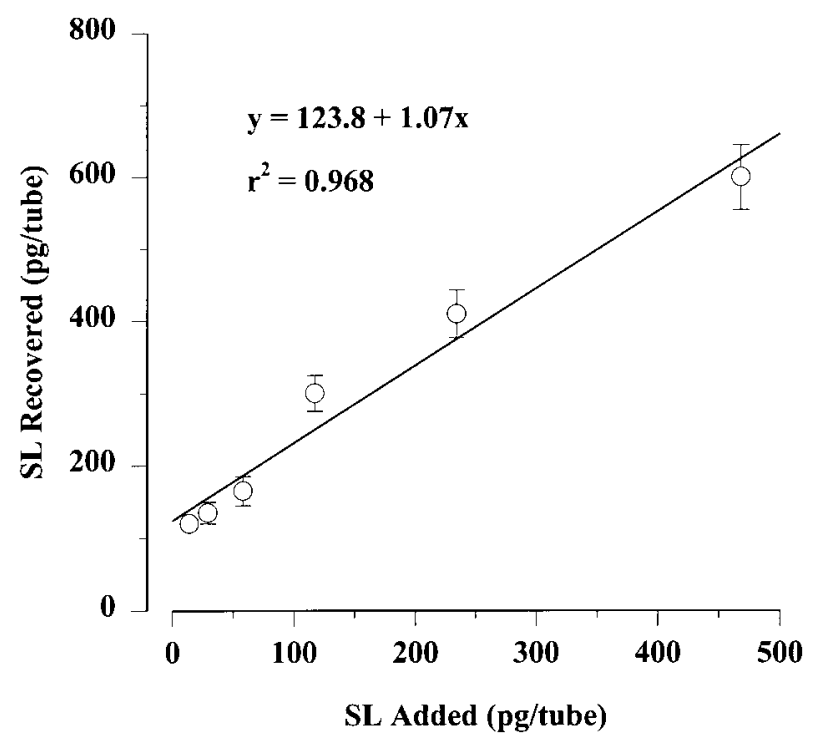

Figure 4 Recovery of rsSL added to $0 \cdot 1 \mathrm{ml}$ of a plasma pool. The level of SL in this plasma pool is around $1 \cdot 1 \mathrm{ng} / \mathrm{ml}$. Each value is the mean \pm S.E.M. of two or three separate determinations.

presence of $\mathrm{GH}$ receptors has been demonstrated in erythroid, lymphoid and myeloid cells of gilthead sea bream (Calduch-Giner et al. 1995). Furthermore, both $\mathrm{GH}$ and PRL are able to enhance the proliferative response of chum salmon leukocytes (Sakai et al. 1996a), as well as to prime trout phagocytes for in vitro superoxide anion release (Sakai et al. 1996b). In this last work, Sakai and coworkers failed to demonstrate any effect with chum salmon SL $(10-100 \mathrm{ng} / \mathrm{ml})$. However, with the increase of the dose range assayed $(360-12000 \mathrm{ng} / \mathrm{ml})$, we found that rsSL is able to enhance the mitochondrial activity of gilthead sea bream phagocytes (Fig. 6). A bell-shape

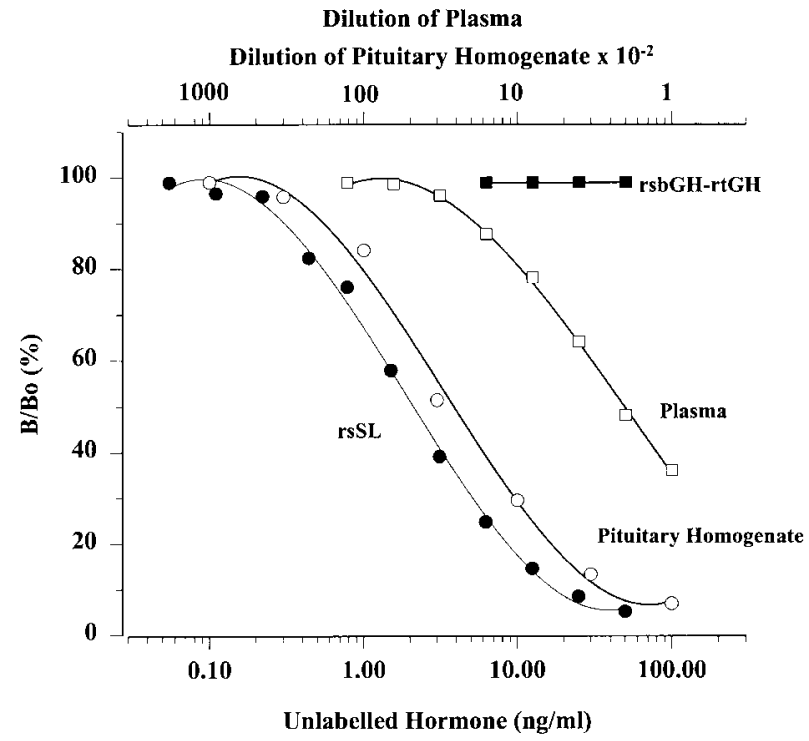

Figure 5 Competitive displacement of ${ }^{125} \mathrm{I}$-rsSL bound to rabbit antiserum by pituitary hormones, and serial dilutions of plasma and sole pituitary homogenates. Initial dilution of pituitary homogenate: $1 \mathrm{ml}$ RIA buffer/100 g body weight.

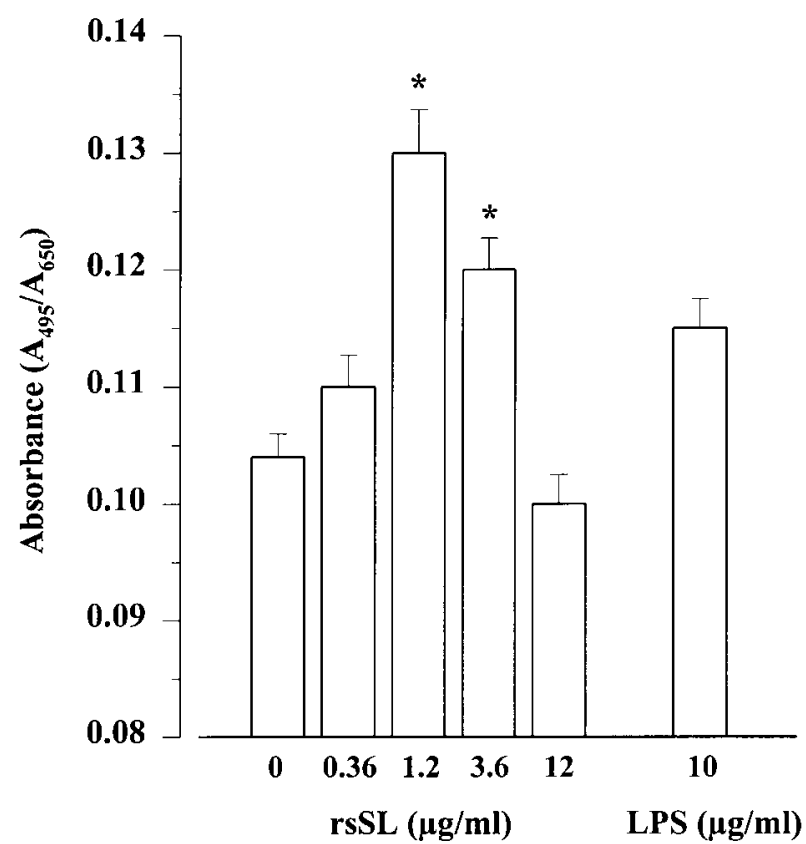

Figure 6 Representative graph of the effect of rsSL and LPS on in vitro XTT cleavage by gilthead sea bream phagocytes. Each value is the mean \pm S.E.M. of four to six replicates $\left({ }^{*} P<0 \cdot 05\right)$.

dose-response curve was obtained with a maximum at $1200 \mathrm{ng} / \mathrm{ml}(50 \mathrm{nM})$, similar to that established with $\mathrm{rtGH}$ (Calduch-Giner et al. 1997). Compared with $\mathrm{rtGH}$, the minimum effective dose of rsSL is $5-10$ fold higher, but the diminished response following LPS priming suggests 
that the SL effect cannot be attributed to bacterial contaminant of our recombinant product. At the present time, it remains to be established whether this SL action is mediated by $\mathrm{SL}$ and/or GH/PRL receptors. In any case, this XTT assay seems to be suitable for monitoring SL bioactivity, in a manner similar to that proposed for GH. In fact, in comparison with a traditional weight gain bioassay, a less time-consuming and more accurate measure of GH biopotency is accomplished with cell proliferative assays, using stable clones of mouse myeloid cells transfected with a full length cDNA coding for $\mathrm{GH}$ receptors (Roswall et al. 1996).

In summary, in contrast to previously isolated pituitary SLs, rsSL is a protein with long-term stability which can be used to develop sensitive and easily reproducible assays. The capacity of rsSL to activate gilthead sea bream macrophages indicates that this protein retains, at least in part, biological activity. Therefore, both this and other recombinant products can provide a useful tool to further clarify the physiological role of fish SL.

\section{Acknowledgements}

We thank Eurogentec for providing rtGH, and NIHNIDDK for the supply of oGH. This work is supported in part by a grant of Ministerio de Educación y Ciencia, Spain (AGF95-0058). J A C-G was a recipient of a research grant from the Generalitat Valenciana.

\section{References}

Astola A, Pendón C, Ortíz M \& Valdivia MM 1996 Cloning and expression of somatolactin, a pituitary hormone related to growth hormone and prolactin from gilthead sea bream, Sparus aurata. General and Comparative Endocrinology 104 330-336.

Calduch-Giner JA, Sitjà-Bobadilla A, Alvarez-Pellitero P \& PérezSánchez J 1995 Evidence for a direct action of growth hormone on haemopoietic cells of a marine fish, the gilthead sea bream (Sparus aurata). Journal of Endocrinology 146 459-467.

Calduch-Giner JA, Sitjà-Bobadilla A, Alvarez-Pellitero P \& Pérez-Sánchez J 1997 Growth hormone as an in vitro phagocyteactivating factor in the gilthead sea bream (Sparus aurata L.). Cell and Tissue Research 287 535-540.

Cavari B, Noso T \& Kawauchi H 1995 Somatolactin, a novel pituitary protein: isolation and characterization from Sparus aurata. Molecular Marine Biology and Biotechnology 4 117-122.

Dores RM, Hoffman NE, Chilcutt-Ruth T, Lancha A, Brown C, Marra L \& Youson J 1996 A comparative analysis of somatolactinrelated immunoreactivity in the pituitaries of four neopterygian fishes and one chondrostean fish: an immunohistochemical study. General and Comparative Endocrinology 102 79-87.

Gala RR \& Shevach EM 1993 Influence of prolactin and growth hormone on the activation of dwarf mouse lymphocytes in vivo. Proceedings of the Society for Experimental Biology and Medicine 204 224-230.

Iraqui F, Gong Z \& Hew CL 1993 Isolation and characterization of somatolactin genes from two cold water marine teleosts, lumpfish (Cyclopterus lumpus) and halibut (Hippoglossus hippoglossus). Molecular Marine Biology and Biotechnology 2 96-103.
Johnson LL, Norberg B, Willis ML, Zebroski S \& Swanson P 1997 Isolation, characterization, and radioimmunoassay of Atlantic halibut somatolactin and plasma levels during stress and reproduction in flatfish. General and Comparative Endocrinology 105 194-209.

Kakizawa S, Kaneko T, Hasegawa S \& Hirano T 1993 Activation of somatolactin cells in the pituitary of the rainbow trout Oncorhynchus mykiss by low environmental calcium. General and Comparative Endocrinology 91 298-306.

Kaneko T \& Hirano T 1993 Role of prolactin and somatolactin in calcium regulation in fish. Journal of Experimental Biology 184 $31-45$.

Kaneko T, Kakizawa S, Yada T \& Hirano T 1993 Gene expression and intracellular localization of somatolactin in the pituitary of rainbow trout. Cell and Tissue Research 272 11-16.

Le Bail P-Y, Mourot B, Zohar Y \& Pérez-Sánchez J 1993 Application of a sensitive radioimmunoassay for the measurement of growth hormone in gilthead sea bream (Sparus aurata) and other sparid fish. Canadian Journal of Zoology 71 1500-1505.

Lu M, Swanson P \& Renfro JL 1995 Effect of somatolactin and related hormones on phosphate transport by flounder renal tubule primary cultures. American Journal of Physiology 268 R577-R582.

Martínez-Barberá JP, Pendón C, Rodríguez RB, Pérez-Sánchez J \& Valdivia MM 1994 Cloning, expression and characterization of a recombinant gilthead sea bream growth hormone. General and Comparative Endocrinology 96 179-188.

Martínez-Barberá JP, Pendón C, Martí-Palanca H, Calduch-Giner JA, Rodríguez RB, Valdivia MM \& Pérez-Sánchez J 1995 The use of recombinant gilthead sea bream (Sparus aurata) growth hormone for radioiodination and standard preparation in radioimmunoassay. Comparative Biochemistry and Physiology 110A 335-340.

Murphy WJ, Rui H \& Longo DL 1995 Effects of growth hormone and prolactin. Immune development and function. Life Sciences $\mathbf{5 7}$ $1-14$.

Olivereau M \& Rand-Weaver M 1994 Immunocytochemical study of the somatolactin cells in the pituitary of pacific salmon, Oncorhynchus nerka, and O. keta at some stages of the reproductive cycle. General and Comparative Endocrinology 93 28-35.

Ono M, Takayama Y, Rand-Weaver M \& Sakata S 1990 cDNA cloning of somatolactin, a pituitary protein related to growth hormone and prolactin. Proceedings of the National Academy of Sciences of the USA 87 4330-4334.

Parhar IS \& Iwata M 1994 Gonadotropin releasing hormone (GnRH) neurons project to growth hormone and somatolactin cells in the steelhead trout. Histochemistry 102 195-203.

Pendón C, Martínez-Barberá JP \& Valdivia MM 1994 Cloning of a somatolactin-encoding cDNA from sole (Solea senegalensis). Gene 147 227-230.

Pendón C, Martínez-Barberá JP, Ortíz M \& Valdivia MM 1996 Bacterial production and purification of the fish pituitary hormone somatolactin. Protein Expression and Purification 7 389-394.

Pendón C, Astola A, Pérez-Sánchez J \& Valdivia MM 1998 Release of glycosylated and non-glycosylated forms of somatolactin by fish pituitary culture in vitro. Trends in Comparative Endocrinology and Neurobiology (In Press).

Pérez-Sánchez J, Martí-Palanca H \& Le Bail P-Y 1994 Homologous growth hormone $(\mathrm{GH})$ binding in gilthead sea bream (Sparus aurata). Effect of fasting and refeeding on hepatic GH-binding and plasma somatomedin-like immunoreactivity. Journal of Fish Biology 44 287-301.

Planas JV, Swanson P, Rand-Weaver M \& Dickhoff WW 1992 Somatolactin stimulates in vitro gonadal steroidogenesis in coho salmon, Oncorhynchus kisutch. General and Comparative Endocrinology 87 1-5

Rand-Weaver M \& Swanson P 1993 Plasma somatolactin levels in coho salmon (Oncorhynchus kisutch) during smoltification and sexual maturation. Fish Physiology and Biochemistry 11 175-182. 
Rand-Weaver M, Noso T, Muramoto K \& Kawauchi H 1991a Isolation and characterization of somatolactin, a new protein related to growth hormone and prolactin from Atlantic cod (Gadus morhua) pituitary glands. Biochemistry 30 1509-1515.

Rand-Weaver M, Baker B \& Kawauchi H $1991 b$ Cellular localization of somatolactin in the pars intermedia of some teleost fishes. Cell and Tissue Research 263 207-215.

Rand-Weaver M, Swanson P, Kawauchi H \& Dickhoff WW 1992 Somatolactin, a novel pituitary protein: purification and plasma levels during reproductive maturation of coho salmon. Journal of Endocrinology 133 393-403.

Rand-Weaver M, Pottinger TG \& Sumpter JP 1993 Plasma somatolactin concentrations in salmonid fish are elevated by stress. Journal of Endocrinology 138 509-515.

Rand-Weaver M, Pottinger TG \& Sumpter JP 1995 Pronounced seasonal rhythms in plasma somatolactin levels in rainbow trout. Journal of Endocrinology 146 113-119.

Roswall EC, Mukku VR, Chen AB, Hoff EH, Chu H, Mckay PA, Olson KC, Battersby JE, Gehant RL, Meunier A \& Garnick RL 1996 Novel assays based on human growth hormone receptor as alternatives to the rat weight gain bioassay for recombinant human growth hormone. Biologicals 24 25-39.

Sakai M, Kobayashi M \& Kawauchi H 1996a Mitogenic effect of growth hormone and prolactin on chum salmon Oncorhynchus keta leukocytes in vitro. Veterinary Immunology and Immunopathology $\mathbf{5 3}$ 185-189.
Sakai M, Kobayashi M \& Kawauchi H 1996 b In vitro activation of fish phagocytic cells by GH, prolactin and somatolactin. Journal of Endocrinology 151 113-118.

Takayama Y, Ono M, Rand-Weaver M \& Kawauchi H 1991a Greater conservation of somatolactin, a presumed pituitary hormone of the growth hormone/prolactin family, than growth hormone in teleost fish. General and Comparative Endocrinology 83 366-374.

Takayama Y, Rand-Weaver M, Kawauchi H \& Ono M $1991 b$ Gene structure of chum salmon somatolactin: a presumed pituitary hormone of the growth hormone/prolactin family. Molecular Endocrinology 5 778-786.

Zhu Y \& Thomas P 1995 Red drum somatolactin: development of a homologous radioimmunoassay and plasma levels after exposure to stressors or various backgrounds. General and Comparative Endocrinology 99 275-288.

Zhu Y \& Thomas P 1997 Effects of somatolactin on melanosome aggregation in the melanophores of red drum (Sciaenops ocellatus) scales. General and Comparative Endocrinology 105 127-133.

Received 29 April 1997

Revised manuscript received 16 July 1997 Accepted 9 October 1997 